\title{
SPRAWOZDANIE Z KONFERENCJI NAUKOWEJ KRÓL JAN III SOBIESKI I RZECZPOSPOLITA W LATACH 1674-1683, WARSZAWA, MUZEUM KRÓLA JANA III W WILANOWIE, 21 PAŹDZIERNIKA 2014 R.
}

21 października 2014 r. w muzeum wilanowskim odbyła się konferencja poświęcona pierwszemu dziesięcioleciu panowania Jana III uznawanym za okres największych sukcesów monarchy zwieńczony wspaniałą wiktorią wiedeńską. Konferencja została zorganizowana przez Instytut Nauk Historycznych Uniwersytetu Kardynała Stefana Wyszyńskiego w Warszawie przy współpracy z Muzeum Króla Jana III w Wilanowie, a na jej potrzeby udostępniono Salę Białą pałacu wilanowskiego. Było to drugie z zaplanowanych trzech spotkań poświęconych wypełnieniu jeszcze niezapisanych białych plam oraz weryfikacji dotychczasowego stanu badań zajmujących się panowaniem króla, który w historii zapisał się przede wszystkim jako autor wielkiego zwycięstwa nad Turcją. Traktowała głównie o tematach, które w historiografii są albo słabo znane, albo błędnie interpretowane.

Sama konferencja została podzielona na trzy panele. Panel pierwszy Propaganda poprowadziła prof. UW, dr. hab. Jolanta Choińska-Mika, zaś wystąpienia przygotowali dr hab. Jarosław Stolicki (Propaganda antyosmańska w latach 1676-1683), mgr Jan Gustaw Rokita (Funkcje propagandowe medali upamiętniajacych batalię chocimska emitowane $w$ latach 1676-1683) oraz gość z Lwowa - mgr Marta Onyśkiw (Na samym ruszeniu do obozu: propaganda wojskowa Jana III Sobieskiego w latach 1674-1683 - na materiałach uniwersatów królewskich, skierowanych do mieszkańców województwa ruskiego).

Sesja druga Parlamentaryzm prowadzona była przez prof. dra hab. Jana Dzięgielewskiego. Prelekcje wygłosili dr hab. Michał Kopczyński (Kto wybrat Michała Korybuta i Jana III Sobieskiego: elektorzy z województwa mazowieckiego w 1669 i 1674 r.) prezentując niezwykle ciekawą metodę identyfikacji uczestników elekcji poprzez badania statystyczne, dr Robert Kołodziej (Sejmy z lat 1676-1683 na tle funkcjonowania staropolskiego sytemu parlamentarnego w czasach Jana III - próba bilansu), dr Diana Konieczna (Zmagania dworu z opozycja litewska przed sejmem grodzieńskim z 1678-1679 roku) oraz mgr Jarosław Pietrzak (Wobec króla i Rzeczpospolitej. Rola i znaczenie Radziwiłtów w pierwszych latach rządów Jana III Sobieskiego 1674-1683)

Sesja trzecia Wojna przygotowana została w celu charakterystyki militarnego aspektu panowania Jana III, a przewodniczył jej prof. dr hab. Mirosław Nagielski. Referaty wygłosili dr Zbigniew Hundert (Pozycja króla Jana III w wojsku koronnym w latach 1674-1683. Utrzymanie czy tez utrata wplywów wypracowanych $w$ czasie sprawowania godności 
hetmańskiej?), dr Piotr Kroll (Kozaczyzna ukrainna w latach 1677-1683), mgr Jan Jerzy Sowa (Finansowanie wojska koronnego $w$ dobie pokoju 1677-1683) oraz spiritus movens całej konferencji dr Dariusz Milewski (Wojenne interludium: stosunki polsko-mołdawskie w latach 1676-1683).

Każdy z paneli zakończony był niezwykle drobiazgową w niektórych aspektach dyskusją uzupełniającą i konfrontującą wystąpienia prelegentów. Konferencję podsumował prof. dr hab. Marek Wagner wyrażając radość z faktu, że występowali na niej głównie młodzi badacze oraz wyrażając życzenie, by kontynuowali oni swe badania w przyszłości.

Organizatorzy konferencji chcieli...zaprezentować, możliwie wieloaspektowo, problemy społeczne oraz polityczne i militarne wyzwania, w obliczu których stanęła Rzeczpospolita i jej elity w ostatniej ćwierci XVII stulecia. Nie tylko te cele zostały zrealizowane - sama konferencja wytyczyła bowiem nowe kierunki badań wykazując, że ten, tak pozornie dobrze znany okres, charakteryzuje się obszerną problematyką, którą nie warto, a trzeba się zająć. Konferencja Król Jan III Sobieski i Rzeczpospolita w latach 1674-1683 stała się dzięki temu udanym przedsięwzięciem naukowym, będącym punktem wyjścia do budowania dalszej narracji historycznej dotyczącej dziejów panowania tego sarmackiego monarchy. 